\title{
Unexpected Therapeutic Result
}

National Cancer Institute

\section{Source}

National Cancer Institute. Unexpected Therapeutic Result. NCI Thesaurus. Code C62821.

Problem associated with the use of a medical device for therapeutic purposes. 